Article

\title{
Why Do Sustainable Ventures Fail to Attract Management Talent?
}

\author{
Neil Aaron Thompson *(D) and Roosje Eijkemans \\ Department of Management and Organization, School of Business and Economics, Vrije Universiteit \\ Amsterdam, De Boelelaan 1105, 1081 HV Amsterdam, The Netherlands; roosjeeijk@gmail.com \\ * Correspondence: n.a.thompson@vu.nl; Tel.: +31-205-989-001
}

Received: 26 October 2018; Accepted: 15 November 2018; Published: 21 November 2018

\begin{abstract}
Entrepreneurship is widely recognized to play a crucial role in transitioning societies towards sustainability, yet sustainable ventures often have difficulty in attracting talented management employees that are necessary to scale their sustainable opportunities. This study examined 19 qualitative interviews with three interview groups (human resource managers of sustainable ventures, recently hired employees at sustainable ventures, and management professionals looking for employment opportunities) to explain the impediments of attracting management talent and what competitive advantages sustainable ventures may have in the labour market. We discuss how these findings have theoretical and practical implications for scholars and sustainable entrepreneurs by drawing out a number of ways that sustainable ventures may attract management professionals.
\end{abstract}

Keywords: sustainable entrepreneurship; human resources; management professionals; competitive advantage

\section{Introduction}

Entrepreneurship is widely recognized to play a crucial role in transitioning societies towards sustainability by developing and diffusing innovative pro-social and environmental products and services [1]. Scholars of sustainable entrepreneurship argue that persistent market failures create inequality and / or environmental degradation, yet these failures are also sources of opportunity for sustainable entrepreneurial action [2,3]. Sustainable entrepreneurial action can lead to improved physical health, education opportunities, community cohesion and development, and self-reliance of individuals and societies [4]. Moreover, sustainable entrepreneurship helps to reduce deforestation and environmental degradation, counteract climate change, preserve ecosystems, improve agricultural practices and freshwater supply, and maintain biodiversity $[5,6]$. Sustainable ventures are defined as "activities focused on the preservation of nature, life support and community as part of pursuing perceived opportunities to create products, processes and services whose economic and non-economic gains accrue to individuals, the economy and society" [1]. Thus, sustainable entrepreneurship is seen as developing sustainable ventures that, when successful, deliver economic gains for investors and societies, counteract negative social ills and reduce environmental degradation $[7,8]$.

Nevertheless, sustainable ventures, as all ventures, depend on the acquisition of resources and knowledge to grow their sustainable competitive advantage [9]. Indeed, without venture growth, the influence of sustainable ventures on society will continue to be limited to "niche" markets at best, or even ensure their failure over the long-term at worst. To grow, sustainable ventures compete for resources, such as funding from investors, philanthropic dollars, government grants and contracts, market share for customers, and political attention. Recently, several studies have provided evidence that sustainable ventures also compete for the talented management employees (defined as person's with high operational and financial knowledge and expertise) across industry contexts [10], 
and that failure to attract management talent significantly hinders the growth of most sustainable ventures [11,12]. In short, founders can often rely on charisma and enthusiasm to get a sustainable venture off the ground, but reaching the next stage of growth requires specific operational and financial expertise. Attracting people with those skills takes time, and many sustainable ventures find it difficult to attract experienced people for management positions [13,14].

Despite the awareness of the need for venture growth and the difficulties in attracting management talent being recognized, little research seeks to inductively understand why this challenge exists and, conversely, what competitive advantages sustainable ventures may have on the labour market. Keizer et al. [13] mentioned it is possible that sustainable ventures pay less than commercial enterprises, which they argued would explain why few talented management professionals seek employment at sustainable ventures. However, we know very little about the actual recruitment mind-sets of human-resource managers in sustainable ventures, why some talented employees have chosen to work at a sustainable ventures and how management professionals currently on the job market perceive sustainable ventures in their career plans. Sustainable ventures, for instance, could be argued to have a competitive advantage in labour markets as their pro-social and environmental missions are more attractive to a younger generation of management professionals. Accordingly, the purpose of this article is to inductively explore why it is difficult for sustainable ventures to attract management professionals, and what competitive advantages sustainable ventures may have in the labour market.

To do so, this study used an in-depth interview design consisting of 19 interviews with three sample groups: human-resource (HR) managers and new management employees at sustainable ventures, and management professionals currently on the job market. The interviews were analysed using the Gioia method, which is a form of thematic analysis that uses open and axial coding to develop aggregate dimensions. Findings reveal that five dimensions may explain the inability of sustainable ventures to attract management professionals: "visibility", "uncertain career path", "lack of guidance and structure", "HR prioritization" and "over-reliance on personal networks". Aside from these drawbacks, we also found that sustainable ventures may have an advantage when it comes to "autonomy", "personal growth" and "working culture". In the discussion, we develop several theoretical insights to explain these findings as well as practical suggestions on the methods through which sustainable ventures could experiment to enhance their odds of successfully attracting young management talent and minimize the negative perceptions. Taken together, this study contributes by shining light on this common difficulty and pointing out new ways in which sustainable ventures may exploit their organization-specific assets to improve their processes of selection and recruitment.

This paper begins by defining core concepts, namely sustainable entrepreneurship and growth of sustainable ventures. This leads us to review the growth challenges of sustainable ventures and problems of attracting management talent, which ends with our research question. Next, we present the methodology of the study, which includes information about the research context, sample, data collection and analyses. The findings section reports the themes that emerged from the data analyses, and the article ends with a discussion of the theoretical and practical implications of the study.

\section{Literature Review}

In this section, we review the literature on sustainable entrepreneurship, in particular recent insights from the Netherlands where this study takes place. We then review the stages of establishing and growing sustainable ventures and challenges of recruitment of management professionals. We end with a research question that motivates this qualitative research.

\subsection{Sustainable Entrepreneurship}

Persistent market failures lead to social inequality and environmental degradation and, hence, solutions to these failures provide new opportunities for sustainable entrepreneurs to restore economic and environmental sustainability [2,3]. Sustainable entrepreneurs are broadly seen as a unique group of entrepreneurs who prioritize sustainability (e.g., people, planet and profit) in the company's mission 
and everyday commercial activities [5,15]. A growing area of entrepreneurship research finds evidence that sustainable entrepreneurs can succeed in combining profit with pro-social and environmental goals by developing new products and services $[1,6,16]$. Sustainable entrepreneurs are thought to be "true idealists" [17] as they are motivated by personal values [18] that are often linked to ethical standards [19] regarding the simultaneous blend of environmental, social, and economic opportunities [20]. In the Netherlands, where this study took place, sustainable ventures have seen growth in terms of venture foundation as well as annual turnover. The number of sustainable ventures in the Netherlands grew from 2000-2500 to 5000-6000 in the past five years, expanding the sector by about $70 \%$. This has led to a more than $60 \%$ increase in employment to approximately $65,000-80,000$ jobs. Moreover, total revenues rose from about 2 billion in 2010 to 3.5 billion euros in 2015, an increase of 75\% [13].

\subsection{Challenges of Scaling Sustainable Ventures}

According to the resource and knowledge-based views of entrepreneurship [21,22], all ventures, thus both commercial and sustainable ones, must acquire the requisite resources and knowledge to grow a sustainable competitive advantage. Founders are primarily responsible for recognizing and evaluating sustainable opportunities as well as taking initial action towards establishing a new organization $[19,23]$. In this initial phase, the founding team develops the idea and translates it into a prototype product or service. In the start-up phase (typically 1-3 years for these types of ventures), the team develops the prototype, a customer base is established, and performance indicators are identified [10]. Moreover, it is here that the sustainable venture receives its first revenues and attracts additional resources in the form of investments or loans. In the early (2-5 years) and late stages of growth ( $>5$ years), the founding team aims to increase its scale through new channels and markets, and may even look for additional growth beyond the initial products or services [24]. To make this leap into growth, the founding team must attract financial growth capital as well as hire talented employees who improve product or service quality and implement standard management processes $[13,25]$.

However, several recent studies have found that many sustainable ventures fail to achieve a next phases of growth, and, thus, have a limited social or environmental impact [11-14]. Using a survey sample of 182 sustainable entrepreneurs, and interviews with 25 sector experts, investors and public sector representatives, Keizer et al. [13] found one of the principal causes of this difference in success in growth compared to commercial enterprises in the Netherlands is a lack of management talent and complications encountered in attracting such talent. The authors argued that a lack of talent translates into average stage of growth of sustainable ventures to be low with about half of respondents indicating they were in the early-stage growth phase and $20 \%$ in seed- or start-up phases. In sum, the absence of professional management talent is thought to reduce the operational and financial expertise that is necessary to professionalize and organize the new venture, so that growth can be achieved.

\subsection{Research Motivation}

As mentioned previously, little empirical research exists to add insight into finding that sustainable ventures fail to grow their opportunities due to difficulties in attracting talented management professionals. This research gap is surprising as a large body of strategic entrepreneurship literature finds, based on the resource and knowledge-based perspectives, that human capital recruitment is vital for new venture survival and growth in general [26]. Moreover, it is common in the sustainable entrepreneurship literature to state that acquiring human capital is a key resources for the establishment and growth of sustainable ventures [27]. However, Keizer et al. [13] established that difficulties in attracting talented management professionals is seen by founders, experts, investors and public sector representatives to be a key deterrent to growth, but they do not investigate qualitatively why this is the case. There is still scarce research on the mind-set and strategies of human-resource employees and job-seeking professionals regarding the ways in which they aim to recruit or evaluate job opportunities that might explain this difficulty. Therefore, it remains unclear why sustainable ventures often fail to acquire professional talent. On the other hand, little research has investigated the advantages that 
sustainable ventures may have on the labour market. Sustainable ventures have strong pro-social and environmental missions that make them stand out in the labour market as more job-seekers recognize these as pertinent issues for society. These shared aims could be argued to attract likeminded professionals. Consequently, the remainder of this study inductively explores why it is difficult for sustainable ventures to attract management professionals, and the possible competitive advantages that sustainable ventures have in the labour market.

\section{Research Methods}

To answer our research question, we use an individual in-depth interview design with three sample groups. This design allows us to better triangulate reasons for difficulties in attracting management talent and possible competitive advantages by enabling both within and between group analyses. This increases the reliability and validity of our inductive analyses [28]. In this section, we describe the sample selection, data collection and data analysis.

\subsection{Sample Selection}

The first sample group was human-resource (HR) managers at sustainable ventures, who were selected based on the expectation that they would be able to share information about the current ways of selection and recruitment. Furthermore, we expect them to be the most aware of the specific hurdles and difficulties that are encountered when trying to attract management talent, which could then be compared to the perceived effectiveness by the other sample groups. We followed Shepherd and Patzelt's [1] definition of a sustainable venture (i.e., "activities focused on the preservation of nature, life support and community as part of pursuing perceived opportunities to create products, processes and services whose economic and non-economic gains accrue to individuals, the economy and society") (p. 142) to purposefully sample the sustainable ventures in a late start-up or early stage of growth phase (following Stam's [24] definitions). Furthermore, we selected HR managers that are either in part or wholly responsible for the process of selection and recruitment of new employees at the sustainable venture in which they work.

Second, we selected a sample of employees who have recently been hired at sustainable ventures as they have experience of orientating themselves on the job market, as well as knowledge of what working at a sustainable venture entails. From this position, they are best suited to compare their expectations from before and after they were hired, critically examine the flaws in the process of recruitment and disclose the incentives that led them to pursue a job opportunity at a sustainable venture. The selection criterion applied was that the participant has started working for the sustainable venture within four years before the interview.

Thirdly, we selected a sample of recent graduates with a Master's degree in Business Administration at the start of their career. We decided to purposefully sample this group following Keizer et al.'s [13] findings that demonstrated the need for expertise in management specifically. Moreover, we selected them to investigate the factors that influence the choice for their future employer, how they perceived job opportunities at sustainable ventures and thus providing their perceptions of the effectiveness of the current processes of recruitment and selection. Finally, by understanding their expectations of what working at a sustainable venture would entail, we would be able to identify possible discrepancies to the perceptions of the first and second sample groups. The selection criterion used was that the participant has within the last six months before the interview obtained, or will within six months from the interview obtain their Master's degree in the field of Business Administration or Management. We selected these participants based on convenience sampling, thus, using personal networks. All abovementioned selection criteria resulted in the following composition of the sample groups (see Table 1). 
Table 1. Sample characteristics.

\begin{tabular}{|c|c|c|c|c|}
\hline Sample Group & Venture Name & Interviewee Name & Individual/Venture Description & Individual/Venture Characteristics \\
\hline \multirow[t]{3}{*}{ Human resource managers (HR) } & SocialMoney & $\begin{array}{l}\text { STKE-HR-1 } \\
\text { FEFO-HR-2 } \\
\text { KAJA-HR-3 }\end{array}$ & $\begin{array}{l}\text { Offers flexible pension accrual in a } 100 \% \text { sustainable life } \\
\text { cycle fund. Reform the Dutch pension system into a } \\
\text { fairer, flexible and sustainable system. }\end{array}$ & $\begin{array}{l}\text { Legal form (N.V.-company is owned by shareholders but they are not } \\
\text { directly known); founded (2013); SBI-code (64301-investment } \\
\text { services); Employees (6); Net Worth (135,000 euro) }\end{array}$ \\
\hline & CleanBuildings & $\begin{array}{l}\text { NOJO-HR-4 } \\
\text { DAHW-HR-5 }\end{array}$ & $\begin{array}{l}\text { Makes buildings energy neutral through clean, efficient } \\
\text { energy production using patented window glass. }\end{array}$ & $\begin{array}{l}\text { Legal form (B.V.-private limited liability company); founded (2014); } \\
\text { SBI-code (72192- engineering, technological development); } \\
\text { Employees (25); Net Worth (440,000 euro) }\end{array}$ \\
\hline & IntegrationNL & DIWI-HR-6 & $\begin{array}{l}\text { Strives for the economic empowerment of newcomers } \\
\text { and their integration into local communities. }\end{array}$ & $\begin{array}{l}\text { Legal form (Not-for-profit foundation); founded (2017); SBI-code } \\
\text { (94993—support fund); Employees (5); Net Worth (n/a) }\end{array}$ \\
\hline Recent hires (RH) & $\begin{array}{l}\text { SocialMoney } \\
\text { CleanBuildings } \\
\text { IntegrationNL }\end{array}$ & $\begin{array}{l}\text { MESC-RH-1 } \\
\text { JEGL-RH-2 } \\
\text { CAMA-RH-3 } \\
\text { YUZH-RH-4 } \\
\text { FIDA-RH-5 } \\
\text { LASA-RH-6 }\end{array}$ & & \\
\hline \multirow{7}{*}{ Recent graduate (RG) } & & LUVE-RG-1 & $\begin{array}{l}\text { MSc, Business Administration: International } \\
\text { Management }\end{array}$ & Dutch, 23, male \\
\hline & & MIOM-RG-2 & $\begin{array}{l}\text { MSc, Business Administration: Digital Business } \\
\text { Innovation }\end{array}$ & Dutch, 24, male \\
\hline & & ROSC-RG-3 & MSc, Business Administration: Strategy & Dutch, 24, male \\
\hline & & MAGO-RG-4 & MSc, Business Administration: Digital Business & German, 24 male \\
\hline & & BOHE-RG-5 & MSc, Business Administration: Digital Business & Dutch, 24 male \\
\hline & & REKU-RG-6 & MSc, Business Administration: Strategy & Latvian, 24 male \\
\hline & & LOLA-RG-7 & MSc, Business Administration: Digital Business & Dutch, 25 , female \\
\hline
\end{tabular}




\subsection{Data Collection and Analysis}

Interviews took place in April 2018. All interviews were semi-structured, to ensure that the core questions would be discussed, while at the same time allowing for the possibility of identifying original understandings of the issues at hand or unexpected observations from the participants. In most cases, the interview took place at a location of the choice of the subject. In some cases, the interview was held over a phone conversation. Each of the sample groups was asked a different set of questions, although for all interviews similar questions on the three core topics were asked, extracting what the respondent perceived to be potential incentives for working at a sustainable venture, what the perceived drawbacks of working at a sustainable venture were, and if they had any comments on the process of recruitment and selection of sustainable ventures as experienced by the subject. The interviews were recorded and transcribed.

Data analysis was carried out using the Gioia method [29], an established qualitative data analysis technique. The Gioia method uses open and axial coding to identify, analyse and report patterns within data. In the first step, each transcript was read and coded into first order codes (a quotation in a reduced number of words) that indicated an answer to advantages or disadvantages of recruiting management professionals. First-order coding adhered closely to an open coding technique where respondent vocabulary and terminology is prioritized, and interpretation or evaluation is limited. For example, the quotation, "quite a lot of talent [goes] to the bigger corporates because they just give a lot more job security" was coded as "job security provided by corporates" and catalogued under "disadvantages". Second, repeating first-order codes across the groups were matched into second-order codes using axial coding looking for repetition and commonality. This resulted in 5 s-order codes (factors) for disadvantages (visibility, uncertain career path, lack of guidance and structure, HR prioritization, and over-reliance on personal networks) and 3 codes for advantages (autonomy, personal growth and working culture). Finally, we looked for variance in the responses per sample group in order to report the degree of complementarity per second-order code. These second-order codes and variation in responses per sample group are discussed in more detail in the next section.

\section{Results}

In this study, we answered the research questions: "Why it is difficult for sustainable ventures to attract management professionals, and what are the competitive advantages that sustainable ventures may have in the labour market"? This section presents findings of the data collected and analysed above. From the thematic analysis, f eight factors were found. Five of the factors, presented in Section 4.1, detail the reasons sustainable ventures may be at a disadvantage or fail in recruitment practices, while three of the factors, presented in Section 4.2, indicate possible sources of competitive advantages in the labour market.

\subsection{Competitive Disadvantages of Sustainable Ventures}

From the analyses of the data, five potential drawbacks emerged that could make working at a sustainable venture less attractive or were due to failures in recruitment practices. We describe each of these in turn (see Table 2 for an overview and a brief description of the five factors). 
Table 2. Disadvantages of sustainable venture in the labour market for management professionals.

\begin{tabular}{|c|c|c|}
\hline Disadvantages & Explanation & Examples \\
\hline Visibility & $\begin{array}{l}\text { Little awareness or low } \\
\text { expectations of sustainable } \\
\text { ventures }\end{array}$ & $\begin{array}{l}\text { "If you start looking on the internet or LinkedIn or I } \\
\text { don't know, it is just much easier to find the big } \\
\text { companies, because it is difficult to find the smaller } \\
\text { companies". (CAMA-RH-3) } \\
\text { "It's rather challenging to find those companies } \\
\text { because they are really small and they usually do not } \\
\text { really post any vacancies quite ahead of time" } \\
\text { (MAGO-RG-4). }\end{array}$ \\
\hline Uncertain career path & $\begin{array}{l}\text { Negative perception of } \\
\text { opportunity for promotions, } \\
\text { and increased unpredictability of } \\
\text { what their future would look like }\end{array}$ & $\begin{array}{l}\text { "If we're not growing fast enough, you will be stuck } \\
\text { in the same job, for a long time. So that is definitely a } \\
\text { drawback" (KAJA-HR-3). } \\
\text { "In a big corporate you have a job and you know } \\
\text { what you are gonna do. Stability, here you have less } \\
\text { stability" (STKE-HR-1). }\end{array}$ \\
\hline $\begin{array}{c}\text { Lack of guidance and } \\
\text { structure }\end{array}$ & $\begin{array}{l}\text { The absence of a personal learning } \\
\text { or coaching program, including } \\
\text { one-on-one mentoring, or } \\
\text { structural support }\end{array}$ & $\begin{array}{l}\text { "Responsibilities are not very much clear, so people } \\
\text { might not feel that they are not really having impact } \\
\text { yet" (FEFO-HR-2). } \\
\text { "In a way it is sink or swim, so you do have to be able } \\
\text { to manage your own time, come up with your own } \\
\text { ideas. There is not a big support system to lean back } \\
\text { on" (KAJA-HR-3). }\end{array}$ \\
\hline HR prioritization & $\begin{array}{l}\text { The lack of strategic } \\
\text { decision-making, planning or } \\
\text { vision related to recruitment }\end{array}$ & $\begin{array}{l}\text { "We don't have time and a budget to hire a HR } \\
\text { manager. We don't have the time and money to have } \\
\text { one person, even one day a week, do fully HR. So the } \\
\text { recruitment is something that needs to be done on } \\
\text { the side" (STKE-HR-1) } \\
\text { "You need to have a very broad outreach, and then a } \\
\text { very strong selection ... but we are not doing that" } \\
\text { (FEFO-HR-2). }\end{array}$ \\
\hline $\begin{array}{c}\text { Over-reliance on personal } \\
\text { networks }\end{array}$ & $\begin{array}{l}\text { HR managers' use of their } \\
\text { personal network in the } \\
\text { recruitment process }\end{array}$ & $\begin{array}{l}\text { "... other colleagues, so people that are telling } \\
\text { friends, or family or whatever, that we are looking } \\
\text { for people, so that is how most people get to work } \\
\text { here" (STKE-HR-1) } \\
\text { "It feels a lot like the majority of people apply, } \\
\text { because they already know someone who is working } \\
\text { for us" (KAJA-HR-3) }\end{array}$ \\
\hline
\end{tabular}

\subsubsection{Visibility}

The first disadvantage of sustainable ventures in the labour market for management professionals was a severe lack of visibility among their target group of potential new employees. As expressed by FIDA-RH-5, who had recently been hired at sustainable venture, after having been approached directly through his network, "I had not heard of them, let alone that they were hiring". CAMA-RH-3 provided a possible explanation for this, stating, "if you start looking on the internet, or LinkedIn or, I don't know, it's just much easier to find the big companies, and it is difficult to find the smaller companies". MAGO-RG-4, one of the interviewed recent graduates, agreed to this, stating about larger corporations, "they usually have those big brand names, and you are always aware of them. And finding those smaller companies, because they do not have a big presence, like, even if they have an online vacancy or LinkedIn or whatever, it's rather hard to find those companies". Recently hired employees acknowledged this issue, perceiving it as one of the most common reasons graduates do not consider working at sustainable ventures. In addition, a lack of exposure at the universities especially could be one of the main explanations for this issue. ROSC-RG-3 says, "maybe it's the environment at the university. They all go for the big corporates. Like, in-house days, for example, are all for corporates". BOHE-RG-5 stated that because his Master programme does not promote sustainable ventures, thus he has not heard of them, whereas most of his motivated peers search for status-providing jobs at large corporations. This was also reflected in the experiences shared by MESC-RH-1 who said: "older students, now working at corporates, they show it, you hear 
about it, like 'look at me, I'm working at a large corporate', and I think that at smaller companies, less well-known organizations, like sustainable ventures, they [older students] show it less".

\subsubsection{Uncertain Career Path}

Our analysis suggests that talented professionals perceive employment at sustainable ventures as an uncertain career path, which deters them from considering to work for a sustainable venture. HR managers, for example, generally responded attracting young talent proved to be complicated, because they lost "quite a lot of talent to the bigger corporates because they just give a lot more job security" (KAJA-HR-3). Interestingly, among the recent hires and recent graduates, this concern was not a priority. According to one of the interviewed recent hires, "to a graduate, it doesn't really matter so much: if you work at a company and the company goes bankrupt, you can still find a job" (FIDA-RH-5). Rather than worrying about the risk of their job to disappear, they feared to have to stay in the same role for too long. One interviewee, for example, stated that "in sustainable ventures, you can have much impact, but you don't have a crazy career, because who is there for me to rule over. I am never going to be the founder, so this is the second highest after the founder, so that's it, there is no career" (LASA-RH-6). Another interviewee shared this view, describing it with the following words, "because it is a small organization, you can't really get a promotion because there is just no room for that" (JEGL-RH-2). Another respondent said the opportunity to experience different roles within the company as one of the factors that would attract him to a potential employer, giving importance to the fact "that it's not a dead-end job" (REKU-RG-6).

\subsubsection{Lack of Guidance and Structure}

Another theme that surfaced from the analysis of the interviews was a perceived lack of guidance or support, as a negative characteristic of sustainable ventures. HR managers often stated that working at a sustainable venture entails the necessity to be "self-sufficient", "reliant on your own roles and time- management", and to take "responsibility for your freedom" in order "not to get lost within the company" (KAJA-HR-3; DIWI-HR-6; STKE-HR-1). Although they appeared to be aware of the implications of this lack of guidance and self-reliance needed, they also revealed that they did not know how to compensate for the issue. This shows from, for example, one of manager's explanations that "everybody is overworked and overloaded as it is. That gives us very limited room to provide a good coaching and support system" (KAJA-HR-3). Most of the recent hires recognized the lack of guidance within sustainable ventures as well: "The structure is something that I miss sometimes", and "having structured weekly training would have been very helpful," because "it's very chaotic" (MESC-RH-1; LASA- RH-6). However, while recent graduates perceived a need for some guidance and mentoring, they did not see it as a requirement for a future job, but rather considered a potential lack of supervision as "something that you would have to accept" when working at a sustainable venture (BOHE-RG-5).

\subsubsection{HR Prioritization}

Problems with the process of recruitment was brought to the attention by the HR managers themselves. It concerns the absence of strategic prioritization in human resources that they experience. FEFO-HR-2 admits that, while human-resources is vital, "we are not really doing anything now, because we are still such a small company". STKE voiced a similar explanation for this issue, stating that "right now, [recruitment] is just something on the side. We have ten things to do, and we only have time for seven, and recruitment is currently not priority one, or two, or three... It has to be done, but actually, we really don't have a lot of time for that, so we try to do it with the minimum effort" (STKE-HR-1). NOJO agreed and added that, "I think outside organizations could help, but that is for us, still too expensive" (NOJO-HR-4). In some cases, the HR managers seem to be aware of how they could strategically improve their processes in these areas: "If you want to have a good start at recruitment, you need to have a very broad outreach, and then a very strong selection so that you can 
shape the team and be very consequent in what you're doing. And we are not doing that" (FEFO-HR-2). Another HR manager stated other strategy prioritize: "We offer our employees sports facilities every Monday, 17:45. There is a professional instructor that comes here for a 1-h power boot camp. And I think that is really cool, and I am proud of that, and they all join" (NOJO-HR-4). However, the recently hired employee, working for the same company, stated, "I am not the biggest fan of, how to say, 'forced team building.' I am not the type of person that would want to spend, like, work with my colleagues and my free time with my colleagues and do extra stuff, like exercise" (FIDA-RH-5).

\subsubsection{Over-Reliance on Personal Networks}

Finally, we found that recruitment of new employees typically happens through personal networks. This became evident from statements such as, "the strategy is more like, we know the people who start working here", and "I think your network is an important thing, it's the most important thing" (NOJO-HR-4; DIWI-HR-6). However, as FEFO-HR-2 and KAJA stated, attracting through your network could have drawbacks, such as attracting a fairly homogenous group of employees, whereas some, as KAJA stated, "fresh meat" could significantly improve the energy within the team. In the group of recently hired employees, five of the six interviewees had been hired there via someone in their network. However, there is a couple of reasons one could argue that this reliance on social networks is counterproductive. Firstly, there is a comparative disadvantage inherent to this strategy, as in general, sustainable ventures do not have more than fifteen full-time employees and usually even far less. The cumulated social networks of mature firms include many more acquaintances, including potential new employees, than that of the five to fifteen employees at an average sustainable venture. Secondly, presuming that a significant share of the potential employees to be found within the network are former colleagues or other work-related acquaintances, a fair share of them are probably also professionally active in the sustainable venture sector. However, considering that this sector is, although rapidly growing, still rather small and since many of the organizations in this sector face a high demand of young talent rather than a surplus, recruiting within this group is competitive and might not be very effective.

\subsection{Competitive Advantages of Sustainable Ventures}

Our interview data also resulted in reflections about the possible three competitive advantages of sustainable ventures in the labour market. We detail each of these below (see Table 3 for an overview and a brief description of the three factors).

\subsubsection{Autonomy}

Autonomy was often seen a critical advantage for working at a sustainable venture. Whether it was noted as a high level of freedom, high degrees of independence, the absence of strict supervision, or relatively high levels of responsibility, all of the sample groups made frequent mention of these aspects as inherent to working at a sustainable venture. HR managers considered it a necessity for potential new employees, for example, stating "no one is telling you every day exactly what to do, so you have to take your own responsibility and be like a mini-entrepreneur within the company" (STKE-HR-1). Moreover, HR managers stated that "if people are able to be free in who they are and what they want to achieve, this might be the best incentive you could ever have" (FEFO-HR-2). These expectations harmonized with the findings from the recently hired employees, five of whom explicitly mentioned the benefits of it. This included FIDA-RH-5, who praised "the freedom of choosing how you work and what you work on", and "also the fact that you can make suggestions as to how to optimize or to change what you're doing to be a more efficient part of the team or to make the team more efficient". LASA-HR-6 echoed the appreciation of the independence, stating: "I am very independent, and I can capitalize all my talents, because if I would go into a big corporate, for three years, I would just do exactly what someone else tells me to do and here, you know, there is no one micro-managing you. I mean, I am in charge, I call people every day and organize stuff, and I am 
really my own boss". However, among the recent graduates, the preferences for autonomy were important but not all participants agreed. Two recent graduates stressed autonomy as a requirement for choosing their future employer, stating, "I want freedom. I think it is important that one is not given too many restrictions" (LOLA-RG-7) and "what is quite important to me is that you have a high degree of independence, so that you are kind of supported and challenged to come up with your own ideas and your own solutions" (MAGO-RG-4). However, others indicated personal growth as the most important factor.

Table 3. Advantages of sustainable venture in the labour market for management professionals.

\begin{tabular}{|c|c|c|}
\hline Advantages & Explanation & Examples \\
\hline Autonomy & $\begin{array}{l}\text { Independence and responsibility in the role, } \\
\text { the absence of strict supervision, freedom to } \\
\text { pursue own initiatives, } \\
\text { and self-management }\end{array}$ & $\begin{array}{l}\text { "You can make your own decisions, you have your own } \\
\text { responsibility". (NOJO-HR-4) } \\
\text { "I mean I am in charge, I call people every day and organize } \\
\text { stuff and I am really my own boss". (LASA-RH-6) }\end{array}$ \\
\hline Personal growth & $\begin{array}{l}\text { Opportunities for self-development, high } \\
\text { learning curves, and fast rates of increased } \\
\text { responsibility }\end{array}$ & $\begin{array}{l}\text { "Self-development, taking your own responsibilities and the } \\
\text { possibility to grow. Those are the incentives why people } \\
\text { would want to work here". (NOJO-HR-4) } \\
\text { "... the higher learning curve, I would say ... I think that } \\
\text { you will also get more responsibilities. And you've got the } \\
\text { possibility to learn more, or learn quicker". (MIOM-RG-2) }\end{array}$ \\
\hline Working culture & $\begin{array}{l}\text { Non-hierarchical, dynamic atmosphere and } \\
\text { the feeling of contributing to a greater good }\end{array}$ & $\begin{array}{l}\text { "For me that's very important, that I can identify myself with } \\
\text { the values of the company and the ways of working". } \\
\text { (ROSC-RG-3) } \\
\text { "I would prefer working at a rather smaller company, because } \\
\text { I prefer to not have that much of a hierarchical structure and to } \\
\text { be closer to your supervisor and to your boss" (MAGO-RG-4) } \\
\text { "You can really have a direct impact and you can see the } \\
\text { impact on the people. You can contribute to a project and then } \\
\text { see the result and that they're happy" (REKU-RG-6) }\end{array}$ \\
\hline
\end{tabular}

\subsubsection{Personal Growth}

The second possible source of competitive advantage was the understanding that working at a sustainable venture entails increased speed of personal growth, in the sense of self-development and a higher learning curve. According to STKE-HR-1, the current stage of growth of the enterprise implied that "if you hop on now, you can grow really fast". DAHW-HR-5 even stated that "if you want to learn about entrepreneurship, or if you want to learn about the starting steps of any business, you can get that five-fold here". However, similar to what was the case for the theme of autonomy, it was admitted that the HR managers did not yet target these incentives in their recruitment process. Not all recent hires experienced this anticipated steep learning curve in quite the same way. Surprisingly, only one of the recent hires explicitly stated that he experienced an environment that allowed for personal growth (FIDA-RH-5). As JEGL-RH-2 put it, "there are opportunities for growth, but the growth is limited to the growth of the company itself". However, unquestionably, growth and the possibility for fast learning were highly prioritized by the recent graduates. This became evident by statements such as "my priority number one is to grow", "I am looking for a chance to develop myself", "for me, what is most important is actually the role they offer me and what I can learn during that role", and "I am looking for an environment where I can learn, and try, and make errors, but learn from them and develop myself" (REKU-RG-6; BOHE-RG-5; MAGO- RG-4; ROSC-RG-3).

\subsubsection{Working Culture}

While the culture of a sustainable venture is difficult to define, many of the interviewees referred to it as one of the factors that made working at a sustainable venture attractive on the labour market. To the HR managers, the culture comprised multiple things, including free lunch and a relaxed atmosphere (FEFO-HR-2), an incredibly dynamic environment (DAHW-HR-5), the focus on people (DIWI-HR-6), the absence of hierarchy (KAJA-HR-3), and the motivation behind the work, namely that of, "adding value to the society as a whole" (STKE-HR-1). Overall, it was agreed that working culture 
was a significant reason for potential employees to want to work for their sustainable venture. Similar positive experiences were shared by new hires, regarding the friendly "friendly vibe in the office" (JEGL-RH-1), quick interaction with co-workers and superiors (FIDA-RH-5; YUZH-RH-4), the absence of hierarchy (JEGL-RH-1), and, lastly, about the socially inspired motivation for doing the work, or as LASA-RH-6 puts it: "the most important is the "why'". Half of the recent graduates also stated that working culture plays a significant role in their choice of a future employer. ROSC-RG-3, for example, stated, "for me, it is very important, that I can identify myself with the values of the company and the way of working". BOHE-RG-5 also held the company culture in very high esteem because, "a really informal structure and culture, that is something that I thrive in". MIOM-RG-2 adds that "the most important thing is the company within the culture, so nice colleagues, but also the objectives of the company itself, so the goals, and sustainability". However, such views were contested by the other recent graduates who expressed, for example: "for me, it is not a necessity that the employer is doing something socially good or important" (MAGO-RG-4).

\section{Discussion}

While the number of sustainable ventures has grown in many countries in the past few years, recent studies find that these ventures often fail to achieve growth. Hoping to understand the challenges related to venture growth in order to support the sector's expansion, the current study addressed one of the issues that Keizer et al. [13] found to be at the heart of the problem: a lack of management talent. Thus, this study contributes to the growing literature on sustainable entrepreneurship by inductively investigating why it is difficult for sustainable ventures to attract management professionals, and what competitive advantages that sustainable ventures may have in the labour market.

\subsection{Theoretical Contributions}

This study makes a number of theoretical contributions to the study of sustainable entrepreneurship. First, we detail several new conceptual factors beyond wages that may explain why attracting professional management talent proves to be so difficult. "Visibility" and "uncertain career path" are regarded as the largest contributing factors of competitive disadvantage, and we argue they connect well to the notion of "liability of newness" as developed by Stinchcombe [30]. The "liability of newness" hypothesis states that new ventures in new field, such as sustainability, have lower levels of "legitimacy" and, thus, are unable to compete effectively in the labour market against established companies in mature fields, such as management consulting. Legitimacy can be understood in terms of "cognitive legitimacy", which structures awareness and expectations. In our case, new graduates' awareness of the existence of new sustainable ventures, what sort of jobs are available, what they can expect from a career within them and where to find job openings remain unclear. Thus, it seems that new graduates have little awareness and expectations about sustainable ventures and what opportunities exist for professional development, which makes them less competitive on the labour market. Second, and related to the first, the factors "lack of guidance and structure", "HR prioritization" and "over-reliance on personal networks" indicates that the internal strategic priority of founders may remain on the development or delivery of products and services, rather than internal professionalization. These three internal factors stem from a lack of financial and time investment in human-resource recruitment, which makes recruitment seem less important, more informal and subject to favouritism, as evidenced by heavily relying on personal networks. By not strategically prioritizing recruitment and emphasizing personal networks, visibility and awareness in the labour market are also hindered. Third, whereas Keizer et al. [13] proposed that the relatively low wages are the main deterrent for talent to work at a sustainable venture, we found that the influence of the pay on new graduates willingness to work for a sustainable venture is minimal.

Finally, the findings demonstrate that advantages and disadvantages in recruitment are more to do with the "entrepreneurship" than the "sustainability" aspect of the ventures. Each of the disadvantage factors above seems to be applicable to most commercial ventures (in new markets), 
and the "sustainability" part of the sustainable venture was surprisingly considered neither an advantage nor a disadvantage on the labour market for management professionals, which is contrary to propositions put forward by Gast et al. [6] and Schaltegger [31]. Recent management graduates weigh a "supportive working environment" for "personal growth" more highly than the venture's commercial, social and/or environmental mission. In fact, the mission of a potential employer only mattered if it was recognizably negative, such as selling weapons. This could be explained by considering that management education is not oriented towards particular missions, such as sustainability, rather expert management techniques applicable to many forms of organizations. Similar to commercial ventures, sustainable ventures have working environments that are less formalized and hierarchical providing room for personal growth, although, as pointed out, this depends on if the venture is able to achieve growth. Consequently, we propose that sustainable ventures are, in fact, competing for management professionals who are already interested in working at an entrepreneurial venture rather than a mature company, whether it be sustainable, and that sustainable mission may be valued more after recruitment and thus play an important role for employee retention.

\subsection{Practical Contributions}

This study also has a few practical implications for sustainable ventures. First, visibility and awareness can be improved by formalizing recruitment processes. As Zimmerman and Zeitz [32] indicated, achieving venture growth through building legitimacy is necessary to access and acquire resources. Possible courses of action could be to conform to normal procedures (e.g., LinkedIn jobs) and select appropriate venues (e.g., university job fairs or start-up job events). Other suggestions are to have more active social media accounts, lengthening the period between the publishing of the vacancy and the starting date of the job, and other forms of promotion, such as leaflets, to let recent graduates know of opportunities. Second, there seems to be a misconception among the HR managers regarding the value that potential new employees attach to pay and job security. Rather than pay and security, the participants in our study valued an expectation to personally grow into different roles in the organization. There may be an opportunity for HR managers to adjust their strategies to suit the desires of their potential new employees better and to improve their successes in attracting management talent by emphasizing personal growth and incorporating guidance during their first years of employment. Finally, developing strategic action plans for attracting management talent could be very helpful, specifically by indicating a steep learning curve that sustainable ventures can offer in a non-hierarchical, friendly, and dynamic company culture. However, one of their key features, namely social and environmental impact, is less relevant to recent graduates, thus it may be of use to expand the target group for their human resources efforts to reach beyond only those with a high sustainability motivation in favour of those with general entrepreneurial motivations.

\section{Conclusions}

We contribute to the growing literature on sustainable entrepreneurship by inductively investigating why it is difficult for sustainable ventures to attract management professionals, and what competitive advantages that sustainable ventures may have in the labour market. Our findings show that visibility, uncertain career path, lack of guidance and structure, HR prioritization, and over-reliance on personal networks hinder sustainable ventures' ability to attract management talent. However, sustainable ventures offer management professionals more autonomy and personal growth in a meaningful working culture, which may be advantageous. Overall, these dimensions contribute to the literature by revealing several new conceptual factors beyond wages that may explain why attracting professional management talent proves to be so difficult. Future research should explore the generalizability of this study's findings, given interviews were not randomly selected and have a small sample size. Moreover, future research should explore if recruiting experienced managers leads to different insights regarding advantages and disadvantages on the labour market. Finally, there are many reasons a sustainable venture may not achieve growth not considered in this study, 
such as business environments that lack clear property rights, the absence of prices for certain natural resources, beneficiaries tend to lack the means to pay for value creation, and the need to initiate costly institutional change to realize changes to existing rules, public policy, norms, and legislation [12]. Nevertheless, we maintain that future research into attracting professional management will surely help sustainable ventures navigate these complex enterprise challenges unique to their missions of reducing social ills and environmental degradation [33].

Author Contributions: N.A.T. was involved in conceptualization, project administration, supervision, writing, reviewing and edition. R.E. was involved in formal analysis, investigation, methodology, and writing.

Funding: This research received no external funding.

Conflicts of Interest: The authors declare no conflict of interest.

\section{References}

1. Shepherd, D.A.; Patzelt, H. The New Field of Sustainable Entrepreneurship: Studying Entrepreneurial Action Linking What Is to Be Sustained With What Is to Be Developed. Entrep. Theory Pract. 2011, 35, 137-163. [CrossRef]

2. Dean, T.J.; McMullen, J.S. Toward a theory of sustainable entrepreneurship: Reducing environmental degradation through entrepreneurial action. J. Bus. Ventur. 2007, 22, 50-76. [CrossRef]

3. Cohen, B.; Winn, M.I. Market imperfections, opportunity and sustainable entrepreneurship. J. Bus. Ventur. 2007, 22, 29-49. [CrossRef]

4. Wheeler, D.; Mckague, K.; Thomson, J.; Davies, R.; Medalye, J.; Prada, M. Creating Sustainable Local Enterprise Networks. MIT Sloan Manag. Rev. 2005. [CrossRef]

5. Thompson, N.A.; Kiefer, K.; York, J.G. Distinctions not dichotomies: Exploring social, sustainable, and environmental entrepreneurship. In Social and Sustainable Entrepreneurship (Advances in Entrepreneurship, Firm Emergence and Growth); Emerald Books: Bingley, UK, 2011; Volume 13, pp. 201-229.

6. Gast, J.; Gundolf, K.; Cesinger, B. Doing business in a green way: A systematic review of the ecological sustainability entrepreneurship literature and future research directions. J. Clean. Prod. 2017, 147, 44-56. [CrossRef]

7. Choongo, P.; Van Burg, E.; Paas, L.J.; Masurel, E. Factors influencing the identification of sustainable opportunities by SMEs: Empirical Evidence from Zambia. Sustainability 2016, 8, 81. [CrossRef]

8. Patzelt, H.; Shepherd, D.A. Recognizing Opportunities for Sustainable Development. Entrep. Theory Pract. 2011, 35, 631-652. [CrossRef]

9. Gartner, W.B. A conceptual framework for describing the phenomenon of new venture creation. Acad. Manag. Rev. 1985, 10, 696-706. [CrossRef]

10. Choi, D.Y.; Gray, E.R. The venture development processes of "sustainable" entrepreneurs. Manag. Res. News 2008, 8, 558-569. [CrossRef]

11. Tracey, P.; Jarvis, O. Toward a theory of social venture franchising. Entrep. Theory Pract. 2007, 31, 667-685. [CrossRef]

12. Hoogendoorn, B.; van der Zwan, P.; Thurik, R. Sustainable Entrepreneurship: The Role of Perceived Barriers and Risk. J. Bus. Ethics 2017, 1-22. [CrossRef]

13. Keizer, A.; Stikkers, A.; Heijmans, H.; Carsouw, R.; van Aanholt, W. Scaling the Impact of the Social Enterprise Sector; McKinsey \& Company Research Report; McKinsey \& Company: Amsterdam, The Netherlands, 2016.

14. André, K.; Pache, A.C. From Caring Entrepreneur to Caring Enterprise: Addressing the Ethical Challenges of Scaling up Social Enterprises. J. Bus. Ethics 2016, 133, 659-675. [CrossRef]

15. Dixon, S.; Clifford, A. Ecopreneurship-A new approach to managing the triple bottom line. J. Organ. Chang. Manag. 2007, 20, 326-345. [CrossRef]

16. Hall, J.K.; Daneke, G.A.; Lenox, M.J. Sustainable development and entrepreneurship: Past contributions and future directions. J. Bus. Ventur. 2010, 25, 439-448. [CrossRef]

17. Hockerts, K.; Wüstenhagen, R. Greening Goliaths versus emerging Davids-Theorizing about the role of incumbents and new entrants in sustainable entrepreneurship. J. Bus. Ventur. 2010, 25, 481-492. [CrossRef] 
18. Schaltegger, S.; Wagner, M. Types of sustainable entrepreneurship and conditions for sustainability innovation: From the administration of a technical challenge to the management of an entrepreneurial opportunity. In Sustainable Innovation and Entrepreneurship; Wüstenhagen, R., Hamschmidt, J., Sharma, S., Starik, M., Eds.; Edward Elgar Publishing Limited: Cheltenham, UK, 2008; pp. 27-48. ISBN 9781847200.

19. Lenox, M.; York, J.G. Environmental Entrepreneurship. In Oxford Handbook of Business and the Environment; Hoffman, A.J., Bansal, T., Eds.; Oxford University Press: Oxford, UK, 2011.

20. Schaltegger, S.; Wagner, M. Sustainable entrepreneurship and sustainability innovation: Categories and interactions. Bus. Strategy Environ. 2011, 20, 222-237. [CrossRef]

21. Wernerfelt, B. A resource-based view of the firm. Strateg. Manag. J. 1984, 5, 171-180. [CrossRef]

22. Grant, R. Toward a knowledge-based theory of the firm. Strateg. Manag. J. 1996, 17, 109-122. [CrossRef]

23. Parrish, B.D. Sustainability-Driven Entrepreneurship: A Literature Review; University of Leeds: Leeds, UK, 2008.

24. Stam, E. Growth beyond Gibrat: Firm growth processes and strategies. Small Bus. Econ. 2010, 35, 129-135. [CrossRef]

25. Muñoz, P.; Dimov, D. The call of the whole in understanding the development of sustainable ventures. J. Bus. Ventur. 2015, 30, 632-654. [CrossRef]

26. Hitt, M.A.; Ireland, R.D.; Camp, S.M.; Sexton, D.L. Strategic entrepreneurship: Entrepreneurial strategies for wealth creation. Strateg. Manag. J. 2001, 22, 479-491. [CrossRef]

27. Short, J.C.; Moss, T.W.; Lumpkin, G.T. Research in social entrepreneurship: Past contributions and future opportunities. Strateg. Entrep. J. 2009, 3, 161-194. [CrossRef]

28. Eisenhardt, K.M.; Graebner, M.E. Theory Building from Cases: Opportunities and Challenges. Acad. Manag. J. 2007, 50, 25-32. [CrossRef]

29. Gioia, D.A.; Corley, K.G.; Hamilton, A.L. Seeking Qualitative Rigor in Inductive Research: Notes on the Gioia Methodology. Organ. Res. Methods 2013, 16, 13-31. [CrossRef]

30. Stinchcombe, A.L. Social structure and organizations. In Handbook of Organizations; Routledge: Abingdon, UK, 1965; pp. 142-193.

31. Schaltegger, S. The link between 'green' and economic success: Environmental management as the crucial trigger between environmental and economic performance. J. Environ. Manag. 2002, 339-346. [CrossRef]

32. Zimmerman, M.A.; Zeitz, G.J. Beyond survival: Achieving new venture growth by building legitimacy. Acad. Manag. Rev. 2002, 27, 414-431. [CrossRef]

33. Thompson, N.A. Biofuels are (not) the future! Legitimation strategies of sustainable ventures in complex institutional environments. Sustainability 2018, 10, 1382. [CrossRef] 